\title{
Napredki v primarni predelavi lesa listavcev
}

dr. Peter Prislan, Gozdarski inštitut Slovenije, Oddelek za gozdno tehniko in ekonomiko

Objavljeno na spletu 16.01.2022 (https://doi.org/10.20315/IG.2022.0006)

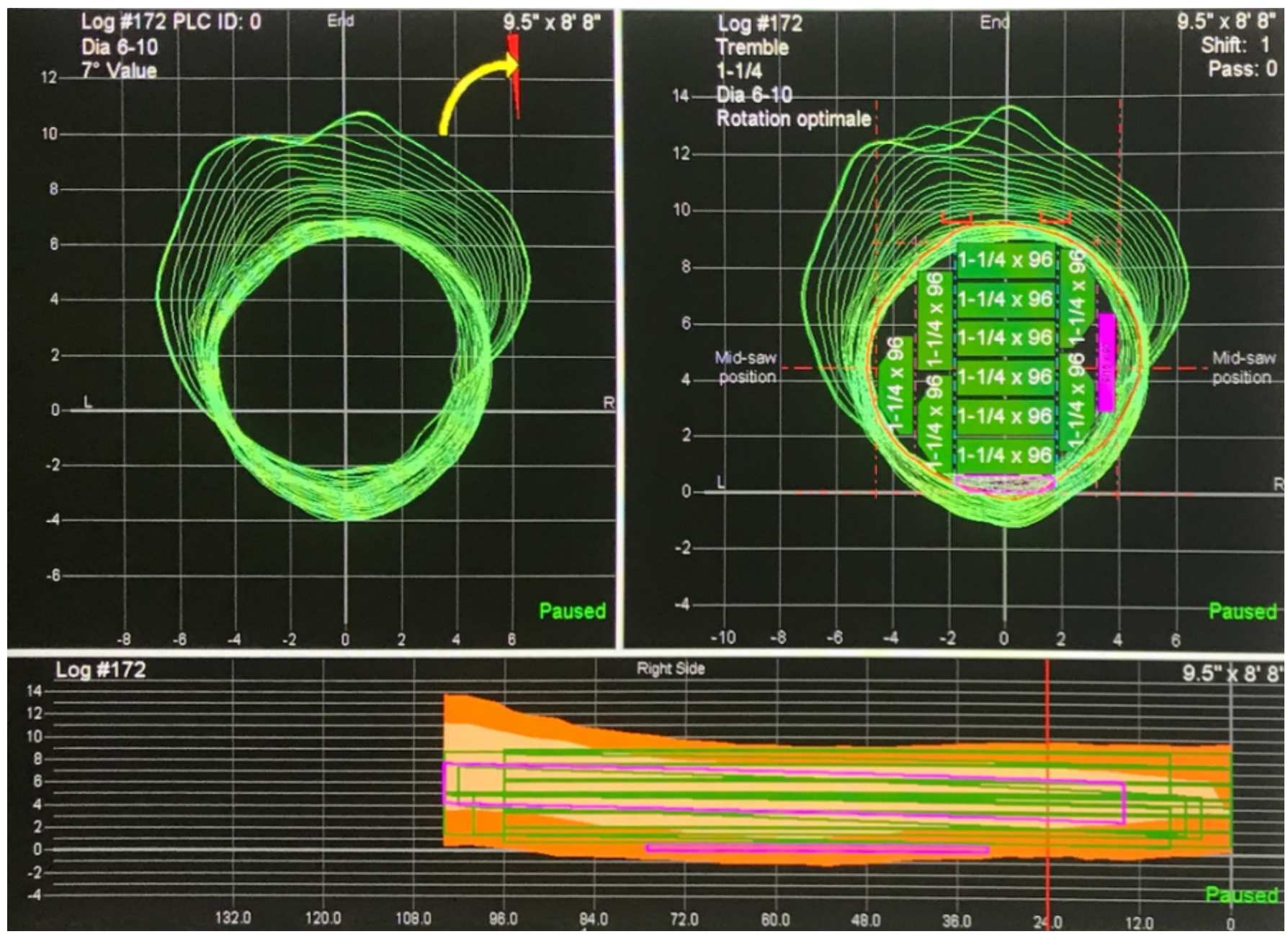

Povzetek prispevka z naslovom »New advances for hardwood processing «, ki je bil objavljen v zadnji številki (avgust / september 2021) revije International forest industries.

Kanadsko podjetje Bois CFM iz province Quebec, ki se ukvarja z razžagovanjem okroglega lesa topola, breze ter macesna in smreke je investiralo v visoko avtomatiziran proizvodni sistem. Slednji jim lahko omogoča večje kapacitete ter manjše proizvodne stroške. Nova postavitev vključuje optimizirano primarno in sekundarno linijo z obračalnim sistemom, ki omogoča avtomatizirano nagibanje in rotacijo 
hlodov. V sistem sta vgrajena dva senzorja za skeniranje, ki zajameta celoten profil hloda. Linija je opremljena s štiri-osnim ter vertikalnim krožnim žaganim agregatom. Stranske deske se preusmerijo v optimizirano robilno linijo, s senzorji, ki omogočajo visoko ločljivo lasersko profiliranje ter zajem slike visoke ločljivosti celega kosa. Podatki iz laserskih in optičnih senzorjev se obdelujejo s programsko opremo, ki omogoča odločanje o sortimentaciji in razrezu na podlagi tehnologije globokega učenja (t.j. področje umetne inteligence, ki obravnava večslojne nevronske mreže).

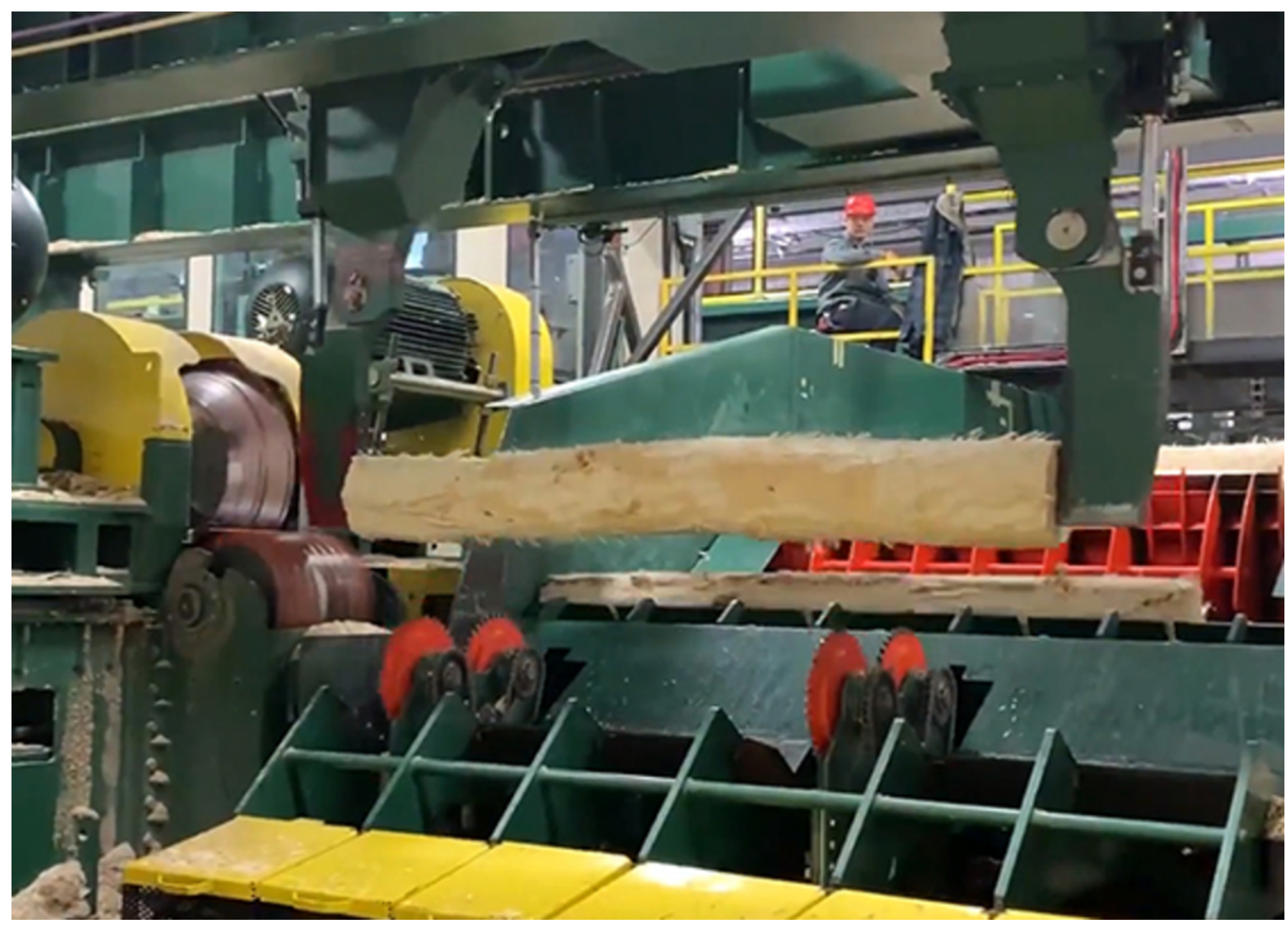

Uporabljena tehnologija se za žagarski obrat, s paletami kot glavnim proizvodom, zdi na prvi pogled pretirana. Vzrok je drevesna vrsta topol (ameriška trepetlika), ki je v obratu največ razžagujejo. Gre za vrsto, ki velja za manj kakovostno z relativno malo možnostmi višanja dodane vrednosti. Zato so se $v$ podjetju preusmerili v masovno proizvodnjo palet iz te drevesne vrste. Za omenjeni topol je značilna krivost, zavita rast ter veliko število grč. Številne napake hlodov so glavni razlog, zakaj se je podjetje odločilo za izbran obračalni in transportni sistem. Slednji omogoča fiksno vpetje hloda, popolni nadzor rotacij in nagibov ter posledično večjo natančnost in boljše izkoristke. Po mnenju proizvajalca USNR je tako imenovan »end-dogger « obračalni in transportni sistem primeren za razžagovanje vseh vrst listavcev.

Namestitev laserskih in optičnih senzorjev je koristna tako v fazi robljenja kot čeljenja. Slednje omogoča optimalne izkoristke vsakega kosa, saj sistem natančno zazna napake v lesu. Zato vsaka izdelana deska, po kakovosti natančno ustreza mestu vgraditve v paleto. Tehnologija globokega učenja npr. sama predlaga kam v paleto vgraditi kose slabše kakovosti. Največji izziv za podjetje je 
predstavljala integracija novih tehnologij tako z vidika človeških virov kot tudi odnosa vodstva, saj so prešli iz delovno intenzivnega v skoraj popolnoma avtomatiziran način proizvodnje. Na proizvodnji linij se je število osebja zmanjšalo iz 16 na 10, osebje pa so prerazporedili na druga mesta kot so vzdrževanje in odprema. Po mnenju podjetja nova tehnologija omogoča večjo fleksibilnost, zato so povečali tudi nabor proizvodov.

Viri:

Spletna stran revije International forest industries (https://internationalforestindustries.com/), Spletna verzija prispevka (https://www.usnr.com/en/content/mi-50-boiscfm-hardwood-sawmill),

Facebook stran

podjetja

B o is

CFM

(https://www.facebook.com/Coop\%C3\%A9rative-foresti\%C3\%A8re-de-la-Matap\%C3\%A9dia-et-ses-filial es-970924436270981/),

Spletna stran podjetja USNR (https://www.usnr.com/en/page/home?dt=1)

Prispevek je nastal v okviru ciljnega raziskovalnega projekta LesGoBio:

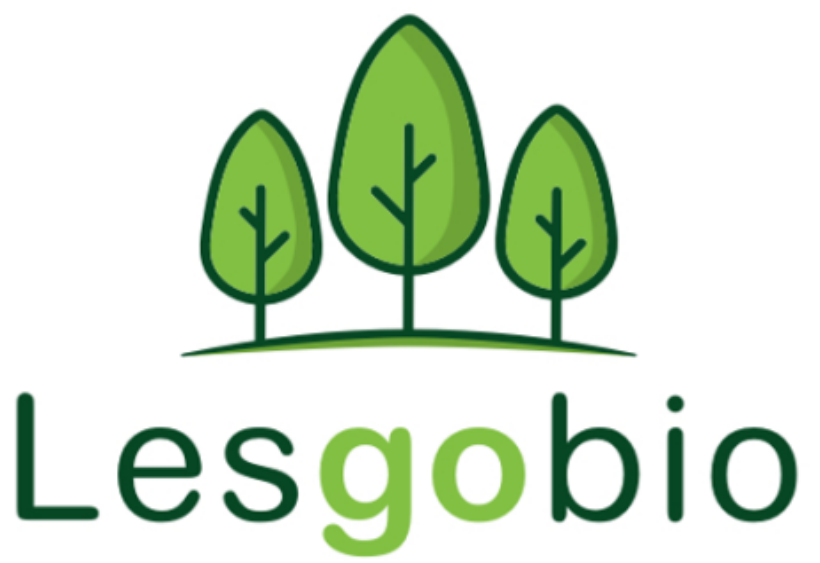

